\title{
Kurdish Diaspora: Creating New Contingencies in Transnational Space
}

\author{
Ahmet Hamdi Akkaya
}

\begin{abstract}
In recent decades, a Kurdish diaspora has begun to appear and its emergence has influenced the nature of the Kurdish question which has until then been a conflict mainly involving the Kurds and the states of the Middle East. Subsequently Kurdish communities have become very active in the diaspora, imposing themselves on the political agendas of most European countries. This change was most dramatic when the Kurds in Iraq began to develop self-government in 1991 which was recognized constitutionally after the fall of Saddam Hussein regime. The Iraqi Kurdistan turned out to be a centre of attraction for the Kurds who were living in diaspora including Turkey, Iran and Syria.

The relationship between the diaspora and the homeland is addressed in this paper in the context of such changes. The aim is to at study how the ongoing nation-building process in Iraqi Kurdistan affects the Kurdish diaspora. It explores how the long enduring Kurdish struggle for nationhood and the relatively new transnational space of the Kurdish diaspora can interact and changes take place in both spaces. It is argued that the Kurdish diaspora has responded to the developments in homeland through different forms of diaspora circulation, rather than returning to homeland which was supposed in the previous studies.

This paper is based on the results of qualitative research which was conducted among the 'elites' of the Kurdish diaspora in Sweden, the UK, the Netherlands and Belgium in 2008.
\end{abstract}

Key Words: Kurdish diaspora, Iraq, homeland, myth of return, diasporic identity.

$* * * * *$

\section{Introduction \\ 'Kurdistanê Azad Çebû' ('A free Kurdistan is born')}

The Kurds, who live in different countries of the Middle East and in the diaspora, have used this popular motto to express the developments in the Kurdish region of Iraq since the collapse of the Saddam Hussein regime. What it implies is the realization of a historical dream of the Kurds which can be summarized as the quest for their own state. This article aims to explore 
the impact of these developments that took place in Iraqi Kurdistan on the Kurdish diaspora.

In general, the nation-building process of the Kurds is related to the nation-building processes in Turkey, Iraq, Iran and Syria, the countries governing the Kurds in the Middle East, which have given rise to different forms of exclusion of Kurds within them. ${ }^{1}$ One of the most important results of this exclusion has been the migration movements of the Kurds which formed a Kurdish diaspora. Therefore, the formation of a Kurdish diaspora has from its beginning been intertwined with the nationhood process of Kurds and the nation-building in their so-called 'host' states.

In this sense the relationship between diaspora and homeland is a very common focal point for studies on the Kurdish diasporas, although this is studied from different perspectives. ${ }^{2}$ In such studies, two arguments concerning the relationship between diaspora and homeland have come to the forefront: 'Almost all Kurdish refugees wish to return to Kurdistan when conditions are appropriate ${ }^{3}$ and the concept of homeland for the members of diaspora is vague and ambivalent, since Kurdistan does not exist as a juridical- political reality. ${ }^{4}$

This article aims to advance on these two arguments, assuming the conditions are now appropriate given the concept of the homeland has become concrete through the self-governing experience in the Kurdish region of Iraq which has turned into a de facto Kurdish state. What effects did the emergence of the de facto Kurdish state in Iraq have on the Kurdish diaspora? Is there a return of Kurdish diaspora? And did they formulate a more inclusive and cohesive discourse of the diasporic identity instead of the 'home-oriented' nationalist discourse based on victimhood?

These questions are discussed from the perspectives of the people who are involved in the diaspora. Qualitative research through semistructured in-depth interviews was conducted with those people who are actively involved in the Kurdish diaspora. ${ }^{5}$ The present analysis draws on 17 life stories through which interviewees referred to the themes of a returning diaspora and the formation of a diaspora identity.

\section{The Formation of Kurdish Diaspora}

The migration movements of Kurds and the formation of a Kurdish diaspora should be discussed in conjunction with the social and historical development of Iraqi Kurdistan. Since the 1970s, we can talk about four great migration movements of Iraqi Kurds. The first three of them occurred as a result of the on-going struggle against the Iraqi state and they had a mainly regional and temporal character. Hundreds of thousands of Kurds had crossed into Iran and Turkey in order to protect themselves against attack by the Iraqi army. Relatively small numbers of peoples have been able to migrate to Europe. However the main Kurdish exodus to Europe from Iraqi Kurdistan 
took place in the 1990s which can be considered as the fourth wave. This started mainly after 1993 due to the economic embargo imposed upon Iraqi Kurdistan and has accelerated during the internal fighting among the Kurdish groups between 1994 and 1998.

The migration movements of the Kurds from Turkey, Iran and Syria have followed their own way, however, it can be generalized that the population movement had a 'transnational' character after the 1960s when the wave of mainly Turkish workers towards West European countries started. Among them the Kurds were a significant number, although in the beginning their Kurdishness was not explicitly stated. Transnational migration has continued in 1970 s and 80 s in the form of refugee movements, because of the oppressive policies of Turkish, Iraqi and Iranian states against the Kurds. In the same period of time, a very wide economic migration has also taken place.

As a result of these different waves of migration, a Kurdish diaspora, composing of different Kurdish communities living in different Western countries has emerged. Although no precise and reliable census of the Kurdish diaspora in Europe has been carried out, the most widely accepted estimates set their number at about 1.4 million in Western Europe and North America, nearly $85 \%$ of them from Turkey. ${ }^{6}$ The number of Kurds from Iraq increased in the 1990s and now they form the largest part of the Kurdish communities in Great Britain, the Netherlands, Sweden and the United States. ${ }^{7}$

This diaspora was mainly based on the 'home-oriented' nationalist discourse which depicted itself as a victim diaspora. ${ }^{8}$ The Kurdish popular narrative of exile considers the Kurds' tragic and traumatic past a major driving force for them entering the diaspora and their practice of 'longdistance nationalism', which they maintain vis-à-vis their 'land of origin'. In this sense, arguments such as 'we are all Kurds' and 'we do not belong here because here is not our country' have been very common among the Kurds in the diaspora, independently of their social or political affiliations. ${ }^{9}$ However the emergence of the de facto Kurdish state in northern Iraq has led to the important changes, including the change in the depiction of the Kurdish diaspora as a victim diaspora and the reconstruction of a new diasporic identity.

\section{The Victim Diaspora and the Myth of Return}

Most of the interviewees narrated their personal migration history and their position in a kind of 'victim diaspora', and their status as 'guest:

When we first got here, everybody was thinking 'we will stay for a limited period of time here'. Many people 
thought of themselves as guests and many still think of themselves as guest.

Generally the interviewees were using the term 'diaspora' to define themselves. Through this usage, they were mostly focusing on dispersion from their homeland of origin and the preservation of a distinctive identity vis-a-vis the host society. However there were also some hesitations in using this term, which may have be due to the fact that they were still considering themselves guests. In this sense, it can be argued that the conception of the diaspora is developing, but not established yet, as one interviewee noted; 'The Kurds are becoming gradually a diaspora. Maybe in the next 20-30 years, Kurds will have genuinely something called Diaspora.'

In terms of the formation process of the Kurdish diaspora, all interviewees narrated their personal experiences as refugees on the basis of the critical events of the nation-building process in Iraqi Kurdistan. They had mainly migrated in the refugee waves of the late 1970's and 1980's and had been politically very active. Therefore they had been very sensitive to the political developments in the homeland which led to the assumption of a returning diaspora, as noted by Safran, 'when the conditions are appropriate, they or their descendants would (or should) eventually return to their ancestral homeland. ${ }^{, 10}$

I assumed that the latest developments in Iraqi Kurdistan could bring about such a return to the homeland for the Iraqi Kurds. However the figures did not bear witness to this. According to the figures provided by of International Organization for Migration (IOM), even though there is a slight increase in the number of people returning to Iraq since 2003, the total number of returnees between 2003 and 2007 did not exceed 11.000. ${ }^{11}$ And not all of them were Kurds. Briefly we cannot assume a 'return movement' among the Iraqi Kurds, although they consider the developments in Iraqi Kurdistan successful. In this sense a returning diaspora is a kind of myth which was explicitly described as such by the interviewees:

It would be individual cases. As group I do not expect them to go back. For a simple reason: their living conditions here are much better. The most expectedly what will happen is that they will have a residency here and another there.

However a very limited number of the refuges, mostly from the political and cultural elite of the Kurdish diaspora, have returned to assume posts in the universities and the governmental offices. Some of the interviewees had gone to Iraqi Kurdistan in order to participate into some ongoing projects. Although they had the intention of staying there, they could not. It can be claimed that maybe the developments in Iraqi Kurdistan had not 
reached the level of 'appropriate', which was put forward as a condition for a return in previous studies. The interviewees pointed out many shortcomings, problems and offered critiques related to the current situation in northern Iraq.

Instead of a returning diaspora, alternative forms of diasporic circulation among the members of the Kurdish Diaspora have developed. The development of the self-governing experience in Iraqi Kurdistan since 1991 has opened doors for more contact with the homeland. This process has developed significantly after 2003; for example, the opportunity of direct flight between the diaspora and the homeland has accelerated transnational connections. As one interviewee noted; 'Visiting Kurdistan has become a part of our everyday. There are many families, who stay there for 6 months and here for 6 months.'

Mobility between the diaspora and the homeland took other forms also including the movement of people knowledge and capital. The interviewees seem to be very confident about their roles as actors in this process. They mainly considered the diaspora as involving human capital and the homeland physical capital, especially the economic capital. This became very obvious when they talked enthusiastically about the various projects which they had developed. They saw this period as a construction process and the 'making of the project' as the most popular way of communicating with the homeland.

Another interesting finding about the relationship between the diaspora and the homeland is the changing mentality of the political forces in Iraqi Kurdistan towards diasporic Kurds. As one interviewee stated;

Until the 90's, the political forces in Iraqi Kurdistan were seeing diaspora Kurds as lost. During the 90's, there has been a significant change in their attitude. They came to look at diaspora Kurds as a national resource to be used and to be accounted for.

However this increasing contact between the diaspora and the homeland can also create tension due to changing expectations. In general, the leadership in Iraqi Kurdistan expects the Kurds in the diaspora just to help with the building of the country and lobby for it. On the contrary members of the Kurdish diaspora criticise the Kurdish authorities for having clear expectation but no clear policy towards the diaspora. The members of the diaspora also consider themselves as being more 'modern' and 'developed' than those Kurds with political power. Some respondents, for example, talked about how the discourse of democracy is stronger in the diaspora than in Iraqi Kurdistan. This has the possibility of creating a cleavage in the relationship between the diaspora and the homeland. As noted by one 
interviewee; 'In the past the Turkish, Syrian, Iranian or Iraqi elites were oppressing us. If the Kurdish elites were as bad as them, what difference does it make for me?'

Consequently it might be premature to assess increasing movement between the diaspora and the homeland and other forms of diaspora circulation have changed the main pattern of the relationship between the diaspora and the homeland.

\section{The Diaspora and Identity}

Modern Kurdish identity which has largely developed as a reaction to cultural and political domination by the Turks, Persians and Arabs, has a very fragmented structure based on its internal as well as transnational character. ${ }^{12}$ The emergence of the diaspora had an explicit impact on the ethno-national identity of the Kurdish immigrants in the sense that they discovered their Kurdishness in the diaspora. Asnoted by one interviewee:

When I came to Sweden, I just realized that I have no need to be Iraqi since I was no longer under the oppression of the Iraqi regime. I discovered my Kurdishness here.

Another important impact of the diaspora on identity is related to its unifying capability towards the formation of a general Kurdish identity. So the creation of a diasporic identity can make it possible to transcend the fragmented structure of the Kurdish identity. As one interviewee noted:

The Kurds in the diaspora have more in common together than Kurds in Kurdistan. A Kurd in Sulaimaniyah would have very little in common with a Kurd in Diyarbakir in terms of dialect, culture, sense of humour and daily life. But a Kurd from Britain, a British Kurd whose parents are from Diyarbakir and a British Kurd whose parents are from Sulaimaniyah have more in common. They understand each other more and they have values that can actually be matched.

Although diasporic experience has allowed the Kurds in the diaspora to have multiple identities rather than one based on a very strong reference to 'the homeland', most of the interviewees combined this with their newly acquired diasporic identity as such, 'I am Kurdish. I sometimes say British Kurd. But the first thing when someone asks me who are you, with great pride, I say, I am Kurdish.'

In this sense, the homeland has still much importance in defining members of the Kurdish diaspora. Moreover the development of Iraqi 
Kurdistan as a locus for Kurdish national identity has exerted a very positive influence over the members of the diaspora personally, as one interviewee noted:

Even up to 2003, the mental and sentimental power that I had was lesser. After that, when the Kurds became stronger, I felt myself strong as well here. Now the people regard me as somebody valuable, as somebody having a valuable identity.

How they are perceived in Iraqi Kurdistan is much more complex, and sometimes it can even be considered as 'traumatic'. One of the respondents explained this as 'being a guest in both places':

Here, you always have in your mind Kurdistan as homeland, home. When you go home and people think that you do not belong to there, you are a guest and ask 'where are you from?' It creates a feeling that you have lost both, instead of gaining both. Being a guest in both places gives you a strange feeling. That is not comfortable.

\section{Conclusion}

In this article, I have investigated how the Kurdish diaspora has been influenced by the developments in Iraqi Kurdistan. And as a general conclusion, it can be said that the relationship between the homeland and the diaspora has gained a new form rather than a returning diaspora, as it was assumed by the previous studies on the Kurdish Diaspora. The Iraqi Kurds have experienced different forms of diaspora circulation, which involve integration in the host societies as well as keeping the relations to the homeland alive. These new forms of circulation include homeland visits, return-visits, transferring knowledge capital and investment, acting as human capital in developing various projects and lobbying for the homeland. The establishment of the de facto Kurdish state in Iraq has qualitatively affected this process in the sense that it has created a more stable atmosphere and provided more resources to advance it.

More importantly, it appears that people in the diaspora develop a distinct identity in a very general sense, and the assumed identification of the diaspora members themselves with the homeland can take other forms in the course of time.

Last but not the least; we can also talk about a change in the depiction of the Kurdish diaspora. What takes place is a shift from being a victimized, ethno-national, homeland-oriented diaspora to one that is 
orientated towards being a transnational-diasporia. One of the recent studies calls this 'from a victim diaspora to transborder citizenship' ${ }^{13}$ This shift also implies the change in the conception of homeland and the nationhood or nation-building process. In Khayeti's words, 'the practice of transborder citizenship creates a new notion of home, which can be imagined beyond any assimilationist form of state belongingness as it is lived both here and there. ${ }^{14}$ In this sense, the Kurdish diaspora now has much more capability and opportunity to be an influential actor for the general process of Kurdish nationhood.

\section{Notes}

${ }^{1}$ M Van Bruinessen, 'Shifting National and Ethnic Identities: The Kurds in Turkey and the European Diaspora', Journal of Muslim Minority Affairs, vol. 18, no. 1, 1998, pp. 39-53.

${ }^{2}$ O Wahlbeck, Kurdish Diasporas: A Comparative Study of Kurdish Refugee Communities, Macmillan Press, London, 1999.

D E King, When World collide: The Kurdish Diaspora from the Inside Out, Phd., Washington State University, Washington, 2000.

D J Griffiths, Somali and Kurdish Refugees in London: New Identities in the Diaspora, Research in Migration and Ethnic Relations Series, Ashgate, Burlington, 2002.

E Østergaard-Nielsen, Transnational Politics: Turks and Kurds in Germany, Routledge, London, 2003.

M Alinia, Spaces of Diaspora: Kurdish Identities, Experiences of Otherness and Politics of Belonging, Phd., Goteborg University, Goteborg, 2004.

A-C Emanuelsson, Diaspora Global Politics: Kurdish Transnational Networks and Accommodation of Nationalism, Phd., Goteborg University, Goteborg, 2005.

K Khayati, From Victim Diaspora to Transborder Citizenship? Diaspora Formation and Transnational Relations among Kurds in France and Sweden, Phd., Studies In Arts And Science, No. 435, Linköping University, Linköping 2008.

${ }^{3}$ Walhbeck, Kurdish Diasporas: A Comparative Study of Kurdish Refugee Communities, p.106.

${ }^{4}$ Alinia, Spaces of Diaspora: Kurdish Identities, Experiences of Otherness and Politics of Belonging, p. 232.

${ }^{5}$ A.H. Akkaya, The Impact of the Nation-building Process in Iraqi Kurdistan on Kurdish Diaspora, Master Thesis, Ghent University, Ghent, 2008.

${ }^{6}$ Russell-Johnston Report, The cultural situation of the Kurds, presented to Council of Europe Parliamentary Assembly in 7 July 2006, in Council of Europe, viewed on 7/15/2008, 
<http://assembly.coe.int/Main.asp?link=/Documents/WorkingDocs/Doc06/E DOC11006.htm>.

7 Emanuelsson, Diaspora Global Politics: Kurdish Transnational Networks and Accommodation of Nationalism, p. 85.

${ }^{8}$ R Cohen, 'Rethinking 'Babylon': Iconoclastic Conceptions of the Diasporic Experience', New Community, vol. 21, no.1, 1995, pp. 5-18.

R Cohen, Global Diasporas: An Introduction, University College London Press, London, 1996.

9 Khayeti, From Victim Diaspora to Transborder Citizenship? Diaspora Formation and Transnational Relations among Kurds in France and Sweden.

${ }^{10}$ W Safran, 'Diaspora in Modern Societies: Myths of Homeland and Return', Diaspora, vol. 1, no. 1, 1991, pp. 83-99.

${ }^{11}$ From the personal communication with IOM- Iraq Mission, 2007.

12 A Vali, 'The Kurds and their 'others': Fragmented Identity and Fragmented Politics', in The Kurds: Nationalism And Politics, F.A: Jabar \& H. Dawood (eds.), Saqi, Beirut, 2006, pp. 49-79.

M Van Bruinessen, 'Transnational Aspects of the Kurdish Question', Working paper, Robert Schuman Centre for Advanced Studies, European University Institute, Florence, 2000.

${ }^{13}$ Khayeti, From Victim Diaspora to Transborder Citizenship? Diaspora Formation and Transnational Relations among Kurds in France and Sweden. ${ }^{14}$ Ibid., p, 177.

\section{Bibliography}

Akkaya, A.H., The Impact of the Nation-building Process in Iraqi Kurdistan on Kurdish Diaspora. Master Thesis, Ghent University, Ghent, 2008.

Alinia, M., Spaces of Diaspora: Kurdish Identities, Experiences of Otherness and Politics of Belonging. Phd., Goteborg University, Goteborg, 2004.

Cohen, R., 'Rethinking 'Babylon': Iconoclastic Conceptions of the Diasporic Experience’. New Community, vol. 21, no.1, 1995, pp. 5-18.

Cohen, R., Global Diasporas: An Introduction. University College London Press, London, 1996.

Emanuelsson, A-C., Diaspora Global Politics: Kurdish Transnational Networks and Accommodation of Nationalism. Phd., Goteborg University, Goteborg, 2005. 
Griffiths, D.J., Somali and Kurdish Refugees in London: New Identities in the Diaspora. Research in Migration And Ethnic Relations Series, Ashgate, Burlington, 2002.

Khayati, K., From Victim Diaspora to Transborder Citizenship? Diaspora Formation and Transnational Relations among Kurds in France and Sweden. Phd., Studies In Arts And Science, No. 435, Linköping University, Linköping 2008.

King, D.E., When World collide: The Kurdish Diaspora from the Inside Out. Phd., Washington State University, Washington, 2000.

Østergaard-Nielsen, E., Transnational Politics: Turks and Kurds in Germany. Routledge, London, 2003.

Russell-Johnston Report, The Cultural Situation of the Kurds, presented to Council of Europe Parliamentary Assembly in 7 July 2006, in Council of Europe, viewed on 7/15/2008,

<http://assembly.coe.int/Main.asp?link=/Documents/WorkingDocs/Doc06/E DOC11006.htm>.

Safran, W., 'Diaspora in Modern Societies: Myths of Homeland and Return'. Diaspora, vol. 1, no. 1, 1991, pp. 83-99.

Vali, A., 'The Kurds and their 'others': Fragmented Identity and Fragmented Politics', in The Kurds: Nationalism And Politics. F.A: Jabar \& H. Dawood (eds.), Saqi, Beirut, 2006, pp. 49-79.

Van Bruinessen, M., 'Shifting National and Ethnic Identities: The Kurds in Turkey and the European Diaspora'. Journal of Muslim Minority Affairs, vol. 18, no. 1, 1998, pp. 39-53.

Van Bruinessen, M., 'Transnational Aspects of the Kurdish Question', working paper, Robert Schuman Centre for Advanced Studies, European University Institute, Florence, 2000.

Wahlbeck, O., Kurdish Diasporas: A Comparative Study of Kurdish Refugee Communities. Macmillan Press, London, 1999. 
Ahmet Hamdi Akkaya is PhD. Student in the Faculty of Political and Social Sciences at the Ghent University, Belgium, affiliated with the Middle East and North Africa Research Group (MENARG). While his master thesis addressed the impact of the nation-building process in Iraqi Kurdistan on the Kurdish diaspora, his doctoral research deals with the development of PKK and the reconstruction of the Kurdish identity. 